\title{
Balkanologie
}

Balkanologie Revue d'études pluridisciplinaires

Vol. VII, $n^{\circ} 2$ | 2003

Volume VII Numéro 2

\section{Nationalism in Construction: The Memorial Church of St. Sava on Vračar Hill in Belgrade}

Bojan Aleksov

\section{(2) OpenEdition}

\section{Journals}

\section{Electronic version}

URL: http://journals.openedition.org/balkanologie/494

DOI: 10.4000/balkanologie.494

ISSN: 1965-0582

\section{Publisher}

Association française d'études sur les Balkans (Afebalk)

\section{Printed version}

Date of publication: 1 December 2003

Number of pages: $47-72$

ISSN: $1279-7952$

\section{Electronic reference}

Bojan Aleksov, « Nationalism in Construction: The Memorial Church of St. Sava on Vračar Hill in Belgrade », Balkanologie [Online], Vol. VII, n² 2 | 2003, Online since 19 February 2009, connection on 17 December 2020. URL : http://journals.openedition.org/balkanologie/494 ; DOI : https://doi.org/ 10.4000/balkanologie.494 


\title{
NATIONALISM IN CONSTRUCTION : THE MEMORIAL CHURCH OF ST. SAVA ON VRAČAR HILL IN BELGRADE
}

\author{
Bojon Aleksov*
}

During the combat we all saw St. Sava, robed in white, and seated in a white chariot drawn by white horses, leading us on to victory. ${ }^{1}$

The role of St. Sava, whom the late Serbian Patriarch German praised as the "Sun of Serbian heaven" in Serbian oral tradition during medieval and Ottoman period was to always watch over Serbian people ${ }^{2}$. In many popular legends and folk tales he is the creator of miraculous springs, a master of the forces of nature with all features of a God who blesses and punishes. Often cruel in punishing and horrendous in his rage, St. Sava, has the features of a primitive pagan god and, though a Christian saint, in the eyes of popular culture he embodied a pre-Christian pagan divinity or the ancient Serbian god of the underworld3.

In the age of nationalism however, the Serbian cult of St. Sava acquired different tasks representing and reproducing, depending on circumstances, powerful images of national golden age, national reconciliation and unification and/or martyrdom for the Church and the nation. For more than a century

\footnotetext{
'Central European University.

${ }^{1}$ The reply of a Serbian schoolmaster who was serving as a private in the Serbian army in the battle of Kumanovo, waged on the $23^{\text {rd }}$ and $24^{\text {th }}$ of October 1912, on being asked what it was that gave the soldiers such tremendous elan, after the severe grueling they received during the first day's fight (Price (Crawfurd), Balkan Cockpit, London, 1915, p. 154). It was the battle that decided the outcome of the First Balkan War.

2 Patriarch German in a statement to a special edition of intervju, entitled "Rastko, Sv. Sava, Vračar" $01 / 04 / 88$, p. 51.
}

3 Cajkanovic (Veselin), O srpskom vrhovnom bogu (On Serbian Supreme God), Beograd : Srpska kraljevska akademija, 1941. 
now, a church dedicated to this saint is being built in Belgrade, aimed to epitomize and monumentalize these images. In my paper I will interpret the construction of St. Sava Church as an architectural illustration of Serbian nationalism encountering numerous political and ideological shifts of Serbia's troublesome twentieth century. To do so I will attempt to unpack the narrative and images invoked by the Church and other protagonists in the construction. Furthermore, I intend to investigate and reveal political and ideological underpinnings of the institutions and personalities behind the construction, and finally, expose the distance between their objectives and realization.

Though envisaged as a place of worship, I will consider the Memorial Church of St. Sava as a national monument par excellence for several reasons. Firstly, it was initiated in line with the nineteenth century urge to erect monuments to commemorate important personages or patriotic events. Its protracted building continued to share the features of the erection of national monuments, which typically involve production / reproduction / manipulation of their meanings over time. Secondly, national protagonists involved in the construction wrap the motivation behind the project in religious symbolism, which is in line with Benedict Anderson's defining the content of nationalism by dominant cultural systems preceding it, religion being in this case the obvious precedent 4 . However, a closer historical scrutiny and contextualization unveil pragmatic politics aimed at mobilizing popular support behind religious symbolism. This is related to yet another similarity of St. Sava Church building to that of other modern national monuments and that is the involvement of persons and institutions for whom it is a purely secular matter, or the matter of modern secular nationalism. Finally, St. Sava Church achieved a place in the repertoire of national symbols and a status of a focus of not only religious but national rites and rituals.

In order to analyze the motives behind endorsing a church as a national monument I will draw on a wide array of "monument" studies as well situate and relate the construction of St. Sava Church to other national monumentalization projects in Europe 5 . Despite some obvious similarities, especially with Moscow's Church of Christ the Savior, the story of the St. Sava Memorial Church in Belgrade displays many unique features. They stem from this mo-

4 Anderson (Benedict), Imagined Communities : Reflections on the Origin and Spread of Nationalism, London : Verso, 1983, p. 12.

5 Sidorov (Dmitiri), " National Monumentalization and the Politics of Scale : The Resurrection of Christ the Savior in Moscow ", Annals of the Association of American Geographers (AAAG), 90 (3), 2000 ; Atkinson (David), Cosgrove (Denis), "Urban Rhetoric and Embodied Identities : City, Nation, and Empire at the Vittorio Emanuele II Monument in Rome, 1870-1945 ", AAAG, 88 (1), 1998 ; Harvey (David), Monument and Myth: The Building of the Basilica of the Sacred Heart, Oxford : Blackwell, 1985; Koselleck (Reinhart), Jeismann (Michael), eds., Der Politische Totenkult, München : Wilhelm Fink Verlag, 1994 ; Denkmale und kulturelles Gedächtnis nach dem Ende der Ost-West-Konfrontation, Berlin : Akademie der Künste, 2000 ; Michalski (Sergiusz), Public Monuments, London : Reaktion books, 1998. 
nument's peculiar context in the Serbian / Yugoslav history. More significantly, the construction of St. Sava Church stands out as an on-going process, a work-in-progress still open for insertion of new meanings.

The symbolism of St. Sava Church transformed from the visual emblem for the drive at unification of all Serbs at the turn of the twentieth century to the inter-war stress on the Serbian (pre)eminence in multiethnic Yugoslavia to post World War Two Communist suppression of its construction as the symbol of Serbian nationalism, whose revival it indeed represented in the 1980s, only to be abandoned in the 1990 s as the nationalist project fell to disarray. In the following pages I will first look at how the cult of St. Sava evolved and the idea to construct a church as the national monument came into being. This decision required a thorough nationalization and sacralization of the chosen site. I will further focus on the debates about the design for the church that mirrored political divisions among the Serbian artistic and political elites. In the last part I will describe the vicissitudes that followed the never-ending construction and examine how they affected the building of St. Sava Church as a monument in reality and discourse.

\section{RISING UP FROM THE ASHES}

St. Sava was born in 1169 as Rastko, the third son to Nemanja, ruler of Ras, the forerunner of the medieval Serbian State. As a young prince he ran away from the royal court to become a monk Sava on Mount Athos, a tale often told among the Serbs as the greatest example of self-sacrifice ${ }^{6}$. There he founded the first Serbian monastery and began his endeavors for which he later acquired the title of the first Serbian Illuminator / Enlightener 7 . With the remains of his father, the founder of the holy dynasty, Sava later returned to Serbia to reconcile an ongoing feud amongst his brothers. Conflicting sources speak of his influence in obtaining the crown for his brother Stephan from Pope Honorius III in 1217. What is historically more certain is that Sava secured autocephaly for the Serbian national Church from the enfeebled and exiled Byzantine Emperor

\footnotetext{
${ }^{6}$ For a hagiographic account in English see Velimirovic (Bishop Nikolaj), The Prologue from Ochrid, Birmingham : Lazarica Press, 1985 ; J. Matl summarizes the findings on St. Sava's life and influence, listing all major historiographic works on St. Sava (Matl (Josef), " Der heilige Sawa als Begründer der serbischen Nationalkirche. Seine Leistung und Bedeutung für den Kulturaufbau Europas ", in Matl (Josef), Südslawische Studien, München : Südosteuropäische Arbeiten, 63, 1965).

7 The Slavic word prosvetitelj is derived from a verb prosvetiti meaning to sanctify rather than to enlighten. Obolenski translates it as Illuminator (in Obolenski, The Byzantine Commonwealth, London : Weidenfeld and Nicolson, 1971). The Serbian Orthodox Church uses the word Enlightener in its English language publications.
} 
and Patriarch in Nicaea, and became its first Archbishop. Moreover, St. Sava helped to restore Serbs, exposed both to Roman Catholicism and the Bogomil heresy, to the bosom of the Orthodox Church ${ }^{8}$. Upon his death, St. Sava was canonized together with his father in an act that, as historian Blagojevic argues, gave the Serbian people saints " who had come from among their ranks and would in heaven be tireless protectors of the Serbian State, Serbian rulers, Serbian people and the entire patrimony " 9 .

During the four centuries long period of Ottoman domination, which began in the fifteenth century, St. Sava was central for both formal religion and traditional, oral culture, the two forces generally held responsible for keeping alive the national spirit of the Serbs. His miracle working body in the monastery of Mileševa was venerated by pilgrims who came from near and far to implore his intercession. When Serbs began a rebellion against the Turks at the end of sixteenth century, carrying banners with images of St. Sava, Sinan Pasha, an Albanian convert in Ottoman ranks, as some contemporary reports and subsequent tradition have it, decided to remove what was in his opinion the source of their inspiration. In 1594 or 1595, Sinan Pasha brought St. Sava's relics to Belgrade and according St. Sava's hagiographies, burned them on Vraćar hill, its highest point, so that the rebellious Serbs in the Banat, across the Danube, could see the smoke and flames ${ }^{10}$. The exact circumstances however are less clear and the whole issue divided Serbian historiography over the last hundred years, with some even claiming that St. Sava's relics were not burned at all. For the Serbian Church and St. Sava cult promoters on the other hand, the burning of St. Sava relics acquired the outmost importance, through which the Saint gained a posthumous martyrdom, partaking symbolically in his people's suffering "under the bitter Turkish yoke".

In fact, St. Sava posthumous cult when transmuted into legend and poetry during the Ottoman period figured him only in a stereotypical dichotomy of a saint-protector of Christian people versus the infidel Muslim-Turk, epitomized in the image of Sinan Pasha ${ }^{11}$. Among those responsible for bolstering the modern cult of St. Sava as a national hero, not least was the Catholic Habsburg Empress Maria Theresa, whose Empire became a refuge for many Serbs fleeing from the Ottomans. In 1776, she ordered the Synod of Serbian Bishops to pro-

\footnotetext{
${ }^{8}$ See Cirković (Sima), et al., Istorija srpskog naroda vol. II (History of the Serbian People), Beograd : Srpska književna zadruga, 1981, pp. 297-315, 315-328.

9 Blagojević (Milos̆), " On the National Identity of Serbs in Middle Ages ", in Samardžić (Radovan), Duškov (Milan), eds., Serbs in European Civilisation, Beograd, 1993.

${ }^{10}$ Samardżić (Radovan), Istorija srpskog naroda (vol III/1), Beograd : SKZ, 1993, pp. 248-285.

"Detelić (Mirjana), " O mogućnostima rekonstrukcije mitskog lika Sv. Save u srpskoj deseteračkoj epici " (On the Possibilities of Reconstruction of St. Sava's Mythical Personality in Serbian Deca-syllable Epic), Balcanica, 25 (1), 1994, p. 260.
} 
claim St. Sava the sole "patron of Serbian people", in an effort to reduce the number of feast days in the Serbian Church Calendar ${ }^{12}$.

The cult of St. Sava, as we know it today, finally began to emerge only at the beginning of the nineteenth century, at the dawn of the age of nationalism, parallel to the liberation struggles of the Serbs, when it, according to the Church historian, assumed the new role to " nourish national pride and flame the patriotism and readiness for sacrifice $"^{13}$. Over the course of the nineteenth century, secular contents intermingled with religious celebration and national romanticism shifted the focus from ecclesiastical and religious rites to enlightenment ideas, the glorious Slav past and resistance to foreign culture and oppression. The feast of St. Sava left the churches where it originated to become a national school holiday, a celebration of the Serbian language, the Slav idea and a plea for the unification and liberation of Serbs from foreign domination. The cult was continuously enriched with new contents as St. Sava's preserved hagiographies were unearthed and reinterpreted. After Arsenije Teodorović in 1807 , depicted St. Sava reconciling his two brothers over their father's relics, St. Sava's role as unifier became the single most exploited image in the narrative surrounding the cult ${ }^{14}$. National romanticism soon added the first figurative representations of the burning of St. Sava's relics by the Turks. The origins of the hymn "Uskliknimo s ljubavlju " (Let us sing out with our love to St. Sava), whose verses emphasize Serbian unity and renewal are less clear but by the middle of the century it became an unofficial national anthem. Other elements such as processions from churches to schools, performances where schoolchildren recited patriotic poems, and special St. Sava's sermon followed. In 1867 , Vladan Đorđević, a medicine student in Vienna and a future Serbian Prime minister reported : " from Pest to Peć [the seat of the Serbian Patriarchate], from Niš and Timok to the Adriatic sea, in all four countries where Serbian people live thorn apart from each other, and even in all countries and cities of Europe where only few Serbs gather, everywhere is celebrated St. Sava $»^{15}$.

\footnotetext{
${ }^{12}$ The Church calendar featured 13 Serbian, besides the already great number of universal Christian saints, turning the good part of the year into feast and leisure days. In a similar fashion St. Constantine and Helene were proclaimed Greek and Saint Parasceva Romanian patron saints. See Grujić (Radoslav), " Kult Sv. Save u Karlovačkoj mitropoliji XVIII i XIX veka "(The Cult of St. Sava in the Metropolitanate of Karlovci in $18^{\text {th }}$ and $19^{\text {th }}$ Century), Bogoslovlje, 10 (2-3), 1935, p. 143.
}

${ }^{13}$ Grujić (Radoslav), art.cit.

14 The image appeared on the fresco in the Church of the Assumption of Virgin Mary in Zemun. See Medaković (Dejan), " Istorijske osnove ikonografije sv. Save u XVIII veku n (Historical Foundations of the Iconography of St. Sava in the $18^{\text {th }}$ Century), in Babić (Jovan), Blagojević (Dimitrije) et al., Sava Nemanjić - Sveti Sava-istorija i predanje, Beograd : SANU, 1979, p. 400.

${ }_{15}$ Matica, 2, 1867, p. 495, cited in Grujić (Radoslav), art.cit. 
In the late nineteenth century, the veneration of St. Sava acquired additional significance under the direct influence of Russophiles and Slavophiles, whose chief proponent in Serbia was Belgrade Metropolitan Mihailo. Whereas the Holy See featured Cyril and Methodius, "Apostles of Slavs", to strengthen the religious and ecclesiastical adherence of Catholic Slavs and, hopefully, win over those Slavs of the Byzantine rite, the Serbian Church raised the flag of St. Sava to awaken and assemble Serbs scattered in four countries and under diverse ecclesiastical jurisdictions ${ }^{16}$. The campaign for ecclesiastical and national adherence waged in Ottoman Kosovo and Macedonia engaged fully both the Church and the State and one of the most importance auspices under which it was conducted was the Association of St. Sava, formed in 1886 in Belgrade ${ }^{17}$. At the same time, students of Prizren seminary, the first Serbian seminary founded in the area under the Ottomans, christened their association with St. Sava's secular name "Rastko", emblematically blurring and superceding the division between the religious and secular under national imperatives.

In such an overwhelmingly nationalist political atmosphere in Serbia, Metropolitan Mihailo was charged, in 1895, to head the Committee made up of Serbia's foremost citizens for the construction of a church on Belgrade's Vračar Hill, dedicated to the memory of the greatest Serbian saint, Enlightener and Unifier. The idea to build the church on that very spot, where three hundred years earlier Sinan Pasha scattered the ashes of Saint Sava finally became a reality. The Construction Committee sent out a rousing appeal to the Serbian people for funds describing the building of the church on the hill where the saintly ashes were scattered as paying due respect to St. Sava and coming to terms with ancestors, without which the present and future community of St. Sava's descendants could not live in harmony and prosper ${ }^{18}$. In her study on The Political Lives of Dead Bodies, Verdery, though focusing on Serbia, overlooks the greatest Serbian cult of all, in which the "need" of a dead body to get a "proper burial" acquires a new dimension ${ }^{19}$. The sacralization of space or its transformation from the profane to the "other-worldly" is, as Philip Aries has shown, closely linked to the presence of the dead, burial grounds or cemete-

\footnotetext{
${ }^{16}$ Dartel (Geert van), Cirilometodska ideja i Svetosavlje (Cyrillo-Methodian Idea and Svetosavlje), Zagreb : Kršćanska sadašnjost, 1984, is the pioneering attempt to describe the interactions of these two competing ideologies.

17 For the activities of St. Sava Association in Kosovo and Macedonia, see Mikić (Đorde), « Delatnost Društva Sv. Save na Kosovu \{1886-1912\} ", Naša prošlost, 1975, pp. 61-87 ; Hadži-Vasiljević (Jovan). Spomenica Društva SV. Save 1886-1936, Beograd, 1936.

${ }^{18}$ \& The Appeal to the Serbian people $n$ sent out by the Committee for Construction in 1895 , republished in Pešić (Branko), Spomen hram Sv. Save na Vrac̈aru u Beogradu 1895-1988 (St. Sava Memorial Church on Vračar Hill in Belgrade 1895-1988), Beograd : Sveti arhijerejski sinod SPC, 1988, pp. 17-22.
}

${ }^{19}$ Verdery (Katherine), The Political Lives of Dead Bodies, Columbia ; Columbia University Press, 1999. 
ries $^{20}$. It was St. Sava himself who, by bringing back his father's body, fostered this belief, so central to Serbian medieval thought, that the welfare of the kingdom was dependent on its possession of the miracle-working relics of its holy founder ${ }^{21}$. But the relics of St. Sava had been burned so the spreading of ashes performed this task, adding a new dimension to Verdery's study on the political meaning and role played by bones. In St. Sava's hagiography and numerous accounts developed thereafter, St. Sava's ashes were taken by the wind and spread, consecrating the soil wherever his cult was maintained or wherever Serbs lived, dispersed by numerous migrations. The flames that arose also acquired mythical meaning, becoming the "Serbian spiritual hearth " and eternal fire (torch) " that gave us warmth, home and spirit "22. The body did not turn into dust but into light that, according to an article written in the 1980 , " for 390 years warmed the Serbian heart, helping it to keep its national essence, its faith, its language, its Christian Orthodox, its Saint Savaian being " ${ }^{23}$. The actual site was transformed and " the Church grew out of the martyred / suffering dust of St. Sava on Vračar hill " as Metropolitan Amfilohije described $^{24}$. In line with Verdery's observations on other examples, nationalism here manifests itself in a kind of ancestral worship, which is why Anderson suggested treating nationalism as if it belonged with "kinship" and "religion", rather than with any other modern ideology 25 .

Still, before the construction could proceed there were a series of important practical and symbolic actions made in order to prepare the ground for construction or the sacralization and nationalization of the site.

The search for the precise site where the relics had been burned began, long before, shortly after the Serbia's liberation from the Turks and the establishment of its semi-independence in 1830 s. When in 1844, the Ministry of Education officially demanded from Metropolitan Petar, information about the exact whereabouts of the cremation, he warned that " it would be sinful to accept a spot merely according to people's guesses ${ }^{26}$. It was not until a little

${ }^{20}$ Aries (Philippe), The Hour of Our Death, New York : Vintage Books, 1982, pp. 62-71.

${ }^{21}$ Obolenski, op. cit., p. 331.

${ }^{22}$ Bećković (Matija), " Služba Svetom Savi. Hram gradi nas, ne mi njega " (Service to St. Sava. We are not Building the Church. The Church is Building Us), Glas Crkve, 3, 1988, p. 5.

${ }^{23}$ The text of MDJ published in Pravoslavlje on the occasion of the second initiation of works, republished in Pešić (Branko), op. cit., p. 63.

${ }^{24}$ Radović (Amfilohije), " Duhovni smisao hrama Sv. Save na Vračaru u Beogradu " (The Spiritual Meaning of St. Sava Church on Vračar Hill in Belgrade), Gradac, 82-83-84, 1988, p. 185. This article was later published as a separate book.

${ }^{25}$ Anderson (Benedict), op. cit., p. 5.

${ }^{26}$ Jakšić-Durković (Ljubomir), " Traganje za mestom gde je spaljen Sv. Sava n (The Search for the Location where St. Sava was burned), Glasnik Srpske Pravoslavne Crkve, 1946. 
known priest from Belgrade, made a thorough search in 1878 , and reported to Metropolitan Mihailo, a location in Vračar that supposedly had a small church destroyed by the Turks in 1757 , which was, according to people who lived nearby, always spared from hail. Furthermore, he explained to the Metropolitan that the inhabitants did not want to admit this earlier because they feared the Prince would immediately claim the land and they would be moved somewhere further away [sic]. It seems that earthly concerns such as the elevation and visibility of the plateau of Vracar and ready available land for construction played a decisive role in the Metropolitan's decision to accept this location, despite the aforementioned warning of his predecessor. As for the exact year when St. Sava's relics were burned, the Construction Committee asked the Serbian Royal Academy of Sciences for help. The Academy's historians judged that it took place in 1894, but the Metropolitan and the Church nevertheless opted for 1895 , since the year suggested for commemoration already passed by and 1895 was anyhow previously commonly thought to be the year when the burning of relics occurred ${ }^{27}$.

The next important act was the renaming of the surrounding area which was called Englezovac (Englishtown) at the time, owing its name to the wealthy and influential businessman Mackenzie, actually a Scotsman, who owned most of $i^{28}$. A group of citizens gathered as "The Society for the Embellishment of Vračar" on March 31, 1894 to solve this problem and suggested to the City Council the renaming of Englezovac to Savinac [Sava's Hill] ${ }^{29}$. The distinguished participants of the meeting thought it " a shame for the Serbian capital that a whole district be called Englezovac " and unconceivable that a national shrine lies on foreign property. Eventually Mackenzie contributed around eight thousand square meters of his land for the cause. As he died before legal formalities were completed, this decision befell his heir, a devout Protestant preacher, Gratan Guinness, who assured that their English names were inscri-

27 Jakšić-Durković (Ljubomir), Podizanje Hrama Svetoga Save na Vračaru u Beogradu, (The Erection of the Church of St. Sava on Vračar Hill in Belgrade), Beograd : Sveti arhijerejski sinod SPC, 1986, p. 29. A similar problem occurred in Hungary at that time in connection to the Millenary celebrations. In 1882, the Hungarian government solicited the help of the Acaderny of Sciences to determine the exact year of the Magyar Conquest. But the scholars widely disagreed over the matter and eventually in 1892 the government decided on its own that the Millennium should be commemorated on 1895 . To make it even more absurd, the next year the date had to be postponed for one year by government decree since the time to finalize the buildings and ceremony plans had run out. Gerö (Andras), Heroes Square Budapest, Budapest : Corvina, 1990, p. 6.

${ }^{28}$ As a member of the Plymouth Brethren, Mackenzie came to Belgrade and initiated a number of projects to foster religiosity among the people and the economic development of the country but, largely misunderstood, they all failed and his presence was generally disliked. Jakšić-Durković (Ljubomir). op. cit., p. 44 .

29 The records of this extraordinary meeting for the renaming of this part of Belgrade were kept in full and published in Beogradske ops̈tinske novine (Belgrade City Newspaper) on 17 April 1894. 
bed in the list of Great Benefactors, right after the members of Royal family and senior Church dignitaries ${ }^{30}$. Finally, to paraphrase Antony Smith, Vračar landscape became a sacredscape and ethnoscape ${ }^{31}$.

In 1895, the Committee first built a small church near the spot of the future Memorial Church - the so-called Forerunner Church - and only collected funds until 1904, when it initiated the first competition for the future church, marking one hundredth anniversary of the First Serbian Uprising against the Turks. Most of Serbs still lived outside of Serbia's borders, and many of them still lived under Turks. Thus the choice when to start the construction, its prominent location and envisaged extensive physical layout of the Church indicated from the beginning intentions beyond the religious; its dominance and immensity was to impress and accentuate the Piedmontian role of Serbia in the unification of Serbs. This coupling of the secular and religious dimensions set irreversibly the future position of the Vračar Hill Church in the visions of national monumentalization advanced by ecclesiastic and State hierarchy as well as lay builders of the nation. At that time, other European capitals had large churches inherited from the past or built in the second half of the nineteenth century when they also acquired the function of a national shrine. The erection of national monuments and the commemorative events surrounding them became an established factor in stimulating loyalty to existing institutions and the State. But belated at its start, the pace and profile of the never ending construction on Vračar Hill was throughout the twentieth century disturbed by tragic historical events and even more so by contesting political visions of its symbolism for Serbia.

\section{BYZANTIUM LOST}

After years of weak response from both the people and State institutions in collecting funds and turbulent events that included a bloody dynastic coup, the Construction Committee finally announced a competition for church design in 1905. Given that there was a lack of competent experts in Serbia to judge the architectural submissions for the new church, the Committee engaged the Art Academy of St. Petersburg for this task. Article Two of the competition announcement clearly stated that " the church should be a respecta-

30 Palairet (Michael), "Covek koji je izgradio Englezovac - Fransis Mekenzi u Beogradu (1876-1895) " (The Man who Built Englishtown - Francis Mackenzie in Belgrade 1876-1895), Istorijski casopis, 39, 1992, p. 160.

${ }_{11}$ Smith (Antony D.), Myths and Memories of the Nation, Oxford : Oxford University Press, 1999. pp. 149-159. 
ble monument of Serbian gratitude, paying a due respect to this great and cherished saint and patron of Serbian schools; it should be monumental in size and in the Serbo-Byzantine style ${ }^{32}$. Agreeing to the notion of a free competition for the project, the committee imposed one major condition on the style, although Church dogma does not envisage a single style but only demands a distinct position and spatial direction of church 33 . Why was this style so important?

Serbian Church architecture and painting in the eighteenth century abandoned its traditional Byzantine style and leaned towards contemporary European or more precisely Central European artistic trends found in the Habsburg monarchy34. The Cathedral of Belgrade built in 1841 with its neoclassical style facades and a Baroque bell-tower became the chief achievement and symbol of this new architectural style. It was not until the historicism of the Romantic era brought to the fore the search for the medieval heritage. This task befell the disciples of Viennese Professor Teophil Hansen, who in the 1880 s launched a so-called neo-Byzantine style, which represented a trendy historicist eclecticism based rather artificially on elements of Byzantine, Islamic and medieval Romanic architecture 35 . Though they introduced a Byzantine ordering of space, their designs had little to do with Serbian medieval churches.

At the same time, the nationalist campaign in the still Ottoman Kosovo and Macedonia, carried out by the St. Sava association among others, brought about the (re)discovery of Serbian medieval churches in these areas, notably the church of monastery Gračanica near Priština. The desire to revive the glorious medieval past and furnish Serbia with its own national style in art, was further misled by the misconceptions of the French art historian Millet ascribing Gracanica to the Serbian national genius and characterizing it as the national monument of Serbian architecture under Byzantine influence ${ }^{36}$. Thus the notion of Serbo-Byzantine style arose, a style of architecture dominant in Serbia during the reign of King Milutin at the beginning of the fourteenth cen-

$3^{2}$ The competition announcement was published in srbske novine on 13/05/05.

33 Mirković (Lazar), Pravoslavna Liturgika (The Orthodox Liturgics), Beograd : Sveti arhijerejski sinod SPC, 1982, p. 81.

34 See Jovanovic (Miodrag), Srpsko crkveno graditeljstvo i slikarstvo novijeg doba (Modern Serbian Church Architecture and Painting), Beograd / Kragujevac, 1987, p. 53.

35 Vasic (Pavle), "Crkvena umetnost kod Srba u XVIII and XIX veku " (Serbian Church Art in $18^{\text {th }}$ and $19^{\text {th }}$ century) in Srpska Pravoslavna Crkva 1219-1969, Beograd : Sveti Arijerejski Sinod SPC, 1969, p. 349. On Hansen and its school see Jovanovic (Mlodrag), Srpsko crkveno graditeljstvo i slikarstvo novijeg doba. Beograd : Društvo istoričara umet. Srbije, 1987, pp. 109-130.

${ }^{36}$ Millet (Gabriel), L' Ancien art serbe : les Églises, Paris : E. de Boccard, 1919. 
tury with the Gracanica as its archetype ${ }^{37}$. Out of all spheres of art, the ecclesiastical architecture made the most radical break with European trends, which it abandoned for the sake of a revived Serbian-Byzantine style, regarded as a pure manifestation of the Serbian national spirit. The ascension of this style to the level of undisputed architectural genre was clearly underpinned by a dual imperative to celebrate simultaneously both an ancient and an emerging State ${ }^{38}$. The ideology of national regeneration translated into the language of architecture rejected European influences and proclaimed a return to medieval Serbian golden age.

However, in what was only the first of many difficulties to characterize future construction, the Russian jury informed the Committee that none of the five projects submitted had satisfied the conditions set forth, and considering the importance of the Church it could not suggest any to be put forward for execution ${ }^{39}$. Although the Orthodox hierarchy in Russia at that time still supported the historicist designs of the nineteenth century, the jury was probably looking for something innovative. Within semiofficial artistic circles, the need to revive church architecture was seriously discussed $4^{\circ}$. Still, despite the fact that the projects submitted by Serbian architects were far from the envisaged criteria and that ultimately the jury failed to select a plan, the architectural style and scale, important symbolic and ideological steps in building the church as a National Monument were set. The Serbo-Byzantine style deployed representations of the past aimed to justify the nationalist expansionism of the present.

However, the Balkan wars and the Great War brought the project to a standstill for many years. It was only in 1919, that the work of the Committee was reinitiated under the presidency of the newly elected Patriarch Dimitrije

37 Despite all the glorification in Serbia, this view has a negative consequence, as the Gračanica was viewed outside of Serbia only as a high achievement of a provincial school, while it is in fact the greatest example of the Late Byzantine architecture as shown by the work of Curčić, which shows Serbia's complete turn toward the Byzantine spiritual world and civilization during the reign of King Milutin. See Curčić (Slobodan), Graćanica : King Milutin's Church and Its Place in Late Byzantine Architecture, University Park : Pennsylvania State University Press, 1979. In the inter-war period another great church was built in Belgrade (St. Marko), which was a bare enlarged replica of Gračanica.

${ }^{38}$ The Serbian King Petar also opted for the Serbo-Byzantine style in the competition for the Royal Family Mausoleum church that ran parallel to that for St. Sava Church. See Jovanovic (Miodrag), Oplenac, Topola, 1989 , p. 27.

39 Pesisc (Branko), op. cit. p. 27.

$4^{\circ}$ The commissions by individual of private groups (such as Old Believers) in Russia nurtured freedom in the expression of style. A great star of Russian church architecture of the period, Aleksei Schusev, who later designed the Lenin Mausoleum and other symbols of Soviet power, preached against « the tasteless brilliance of official Orthodox church design " but for " a place of worship whose interior and exterior would exemplify that endearing, naive and at the same time diverse sense of artistry of the Orthodox church $\%$. Quoted in Brumfield (William Craft), A History of Russion Architecture, Cambridge : Cambridge University Press, 1993, p. 432. 
and the protection of King Aleksandar, of newly created Kingdom of Serbs, Croats and Slovenes (Yugoslavia from 1929). The Patriarch insisted that the old plans were irrelevant and that a plan should be developed to reflect the contemporary situation of the Serbian people and State, and to commemorate Serbian achievements of the period. After years of debate, the Committee decided to launch a new competition in 1926, which reiterated some of the previous conditions : " the church should be elevated ; it should be of monumental proportions and accommodate 6 ooo people ", while the style was again un-precisely defined as " in the spirit of old Serbian architecture " $4^{1}$. This time however, the local jury, comprised of the most prominent public figures and renowned architects and civil engineers, deemed the submitted projects as unsatisfactory. Nevertheless, the intellectual and political atmosphere of the period soon determined what the jury could not.

In the new Yugoslav State, the Serbian Church lost much of its privileged position and had to accommodate to religious pluralism. Even though all Orthodox Serbs finally rallied in one State headed by their Monarch, the need for an integrative and bonding nationalist ideology had not receded. The Serbian Church had to assemble dioceses, which were under five different jurisdictions, each claiming a well-established and distinct tradition, modes of administration and political ideas. No less difficult was the integration of Serbs of different cultural and historical backgrounds that found themselves in the new State. For many of them, namely the Serbs from Serbia, it was the first experience of living in a multiethnic country and moreover a multiethnic country where they actually constituted less than a half of its population. Finally, there was the issue of binding the Serbian intelligentsia to the Church with which it was confronted almost from its inception at the end of the eighteenth century, a conflict increasingly perceived as destructive both for the Church and the nation.

It was exactly in this challenging time that the Serbian Church's potential was boosted by the arrival of many prominent Russian clerics and theologians, who together with thousands of their compatriots found solace in the brotherly Yugoslav nation after the October Revolution ${ }^{42}$. Under the influence of the conservative branch of Russian emigration personified in the Karlovci Synod established in Yugoslavia, Serbian theologians and philosophers began to search for different social and State models, for authentic Orthodox answer

$4^{2}$ See Raeff (Marc), Russia Abroad, Oxford : Oxford University Press, 1990, pp. 118-155. N. Zernov, who was one of the Russian émigrés in Belgrade, testifies about this intellectual atmosphere (in Zernov (Nicolas), The Russian Religious Renaissance of the Twentieth Century, London : Darton, Longman \& Todd, 1963. pp. 210-249). 
to what Spengler defined at the dusk of WWI as Decline of the West 43 . The solutions to problems of democracy and capitalism were sought in pre-Modern patriarchal forms of Balkan society, in Byzantine models of harmony in Church and State relations. St. Sava's name was borrowed to label Serbian national ontology - Svetosavlje44. Thus, came the new reinterpretation of St. Sava's heritage, in the form of newly-coined notion of Svetosavlje 45 . It sought to replace St. Sava the Enlightener and patron of children and education, whom one of the Svetosavlje founding fathers described as " having no muscles and blood cells, being like a shadow with a soul made of cobweb $" 4^{6}$. Instead Svetosavlje stood for an integral national principle through which "Christian ethos transformed into Slav ethnos ". Taking the obvious Christianization that Medieval Serbia experienced with St. Sava as a base, Svetosavlje or Saint Savaian ethnosophia became for its promoters "sanctification of the national, the lifting up of national in Christian ". Only national Svetosavlje was the way to co-national, supranational and universal Christianity.

In the newly-founded journal of theology students carrying its name, Svetosavlje received its programmatic exhibition by Russian theologian Teodor Titov. For Titov, Svetosavlje was Christianity permeated with greatest Christian virtues of love, aspiration to perfectionism, self-denial, asceticism together with the new elements such as Pan-Slavism, pan-orthodoxy, and religious tolerance, necessary for the rapprochement with the Yugoslav Roman Catholics47. Another Russian émigré, Sergej Troicki, insisted that Svetosavlje was a Pan-Slavic national ideology of rapprochement and unification of all Slavs. In light of intensification of conflicts with the Catholic Church, young theologian, Danilo Medan, proposed Svetosavlje as a solution, which did not see an enemy in Catholicism, a brotherly Christian religion. Instead, in his view, Svetosavlje objects to the politics of Catholicism which aimed at " enslavement and oppression of Slav peoples, their awakening and development; absorption of their racial and cultural individuality ${ }^{48}$. During 1930 , the au-

43 The study on the influence of Russian émigrés on Serbian religious and secular thought is yet to be written. The translation of Spengler's book to Serbian appeared only in 1937. but was widely discussed earlier. Spengler (Osvald), Propast Zapada, Beograd : Geca Kon, 1937.

44 There were various attempts to translate the term Svetosavlje ranging from Saintsavaism to St. Sava's heritage. Its origins and development are discussed later in the paper. The Church of St. Sava on Vračar Hill is in Serbian called Hram Sv. Save (Temple of St. Sava). In English translation it is referred to as the Church or Memorial Church of St. Sava.

45 See Buchenau (Klaus), " Svetosavlje und Pravoslavlje. Nationales und Universales in der Serbischen Orthodoxie "(forthcoming). It is the first work on the inter-war invention of Svetosavlje.

${ }^{6} 6$ Najdanović (Dimitrije), "Svetosavska paralipornena ", Svetosavlje, 1 (2), 1932, p. 63.

47 Titos (Teodor), " Svetosavlje ", Svetosavlje, 2 (3,4,5), 1933, pp. 97-104

$4^{8}$ Medan (Danilo R.), " Konture Svetosavske ideologije i njen značaj u prošlosti i sadašnjosti " (Contours of Saint Savaian Ideology and its Significance in the Past and Present), Svetosavlje, 6 (2-3), 1937. p. 92. 
thors around Svetosavlje journal developed the polemical attitude towards Islam, Catholicism as well as western culture and atheism in general, which were all perceived as enemies of the Serbian Church and people. All of them however, besides Catholicism, refer to contemporary issues and have nothing to do with the life and work of Saint Sava.

Naturally, the proponents of Svetosavlje fostered the importance of the Memorial Church construction throughout the following period propagating their ideas of national monumentalization. Whereas the idea to build the St. Sava's shrine at the end of the nineteenth century was motivated by his role as a national Enlightener and unifier, the inter-war period transformed it in the symbol of absolute identification of the religion and nation that took place, theoretically with the ideology of Svetosavlje and practically with intensified distancing and animosity between Catholic and Orthodox Churches in the Kingdom of Yugoslavia49. The revived interest in Byzantium, which also arose, was different than the previous romanticist glorification of the golden medieval age ${ }^{50}$. The new claim was that the medieval Byzantine identification of Church, Kingdom and people was absolute, their relationship harmonious and prosperous, exemplified with the numerous great churches built throughout Serbia by kings and the nobility, most of whom still remain as testimonies to the present day.

In 1930, the Construction Committee received a new chairman, the recently enthroned Patriarch Varnava, with whom the Serbian Church entered a period of its greatest construction work, building hundreds of churches throughout the country, twelve in Belgrade alone, all of which still occupy an important position in the city landscape ${ }^{51}$. Recuperating the "great and sacred" endeavor of building the "Cathedral of Serbian Orthodoxy", Patriarch Varnava insisted it should " reflect in its decorations, mosaics and frescoes the whole of Serbian history ${ }^{52}$. Eventually after years of uncertainty he cut the Gordi's knot of contested architectural and political visions and decided to alter the plan. The Committee commissioned two architects, Nestorovic and Deroko, whose works ranked high in the second competition and whose design was

49 The Serbian Orthodox Church exercised previously unseen clericalism during the so-called Concordat crisis in 1937, when it opposed and finally prevented the adoption of Concordat with the Holy See. The Serbian Church complained that the Catholic minority was granted a more favorable position than that enjoyed by the Orthodox majority. Pavlowitch (Stevan K.), Yugoslavia, London : Ernest Benn, 1971, p. 95.

${ }^{5}$ Under generous royal sponsorship, the second congress of Byzantologists took place in Belgrade in 1927, with a variety of events and art exhibitions, receiving high media coverage. See Jovanovic (Miodrag), Srpsko crkveno graditeljstvo i slikarstvo novijeg doba (op. cit.), p. 200.

51 Lečić (Momir), " Izgradnja i obnova crkava i manastra od 1920-1941 " (The Construction and Reconstruction of Churches and Monasteries from 1920-1941), in Srpska Pravoslavna Crkva 1920-1970, Beograd : Sveti arhijerejski sinod SPC, 1971, pp. 65-125.

$5^{2}$ Quoted in Pešić (Branko), op. cit., p. 41. 
reshaped to embody the current ideological leanings, where church's scale and Byzantine look were central. Deroko's concept imitated Constantinople's Saint Sophia's cruciform model with a large dome that replaced the previous ideal model of Gračanica's large nave with five cupolas. The idea behind Belgrade's most ambitiously conceived architectural project was clearly to replicate the most exceptional magnificence and grandeur of the church in Constantinople. The size and design were combined to anticipate the Serbian Church's success in overcoming the deep polarization of the Serbian society and to show that Serbs could unite and grow only with their Orthodox Church.

This decision however instigated the greatest ever controversy among Belgrade's architects and artists 53 . The transformation of architectural design wrought by the Modernist style already expressed in Russia, Germany, Holland and elsewhere acquired many advocates in Belgrade as well. New materials, particularly steel and reinforced concrete, enabled the architect to break from the traditional church form. In the debate that ensued, prolific modernist architects Zloković, Dubavi, Brašovan and sculptor Meštrović rejected the idea of imitating Gračanica or St. Sophia, exclaiming that bonding with the past, rather than with contemporary needs, does not mean artistically creating. Others raised the issue that the Roman Catholic Church launched an international competition, an idea rejected by the Orthodox Church, which acknowledged the right to compete only to Yugoslav citizens and Russian émigrés. To this Patriarch Varnava answered that he preferred the competition to be open only to Serbian architects, even if they were inferior to foreign architects, on the grounds that they could more easily reach the conscience and soul of the Serbian people. The defenders of the Committee's position relied on the ideological appeal of newly founded ideology of Svetosavlje :

what other style could we imagine for the Memorial Church of St. Sava than SerboByzantine, which would not even exist as a special offshoot of Byzantine style, had not St. Sava laid foundations of our medieval Church and culture, so that we could justly call this style Saintsavaian. (...) It is not the matter of copying or imitating one or another church, but of opening further space for the [Saintsavaian] spirit, which is still alive.

The critics on the other hand insisted that the plan was looking backwards, pointing to the long time span that had elapsed since Justinian. Under the Ottoman Empire, these opponents claimed, the Orthodox Church was not allowed to expand and instead of looking forward, it turned inwards and to its "glorious" medieval past. A prominent art critic, Kašanin, joined the barrage against imitating medieval constructions comparing it with writing contem- 
porary history in the style of Middle Age chronicles54. Summing these arguments, architect Bošković points out that even in medieval times there were various styles or variations on a style so that Gračanica or any church could not be taken as a given model55. Furthermore, none of the proposed models offered a solution to the stipulation of a monumental contemporary building : the interior room arrangement was disproportionate ; too decorative a composition of minor ornaments was incongruous to the monumental sizing ; the strivings and needs of contemporary life and the use of new building techniques also demanded a the new solution. St. Sophia, Boškovic thought, was far from Serbia. It was constructed before the Serbs moved to the Balkans, and in the epoch of their great construction activity, it ceased to be a model : "St. Sophia is foreign to us in its type, spirit, even in its total psychological conception, which is aimed at pomp and flash ". Thus, he claimed, if the committee was looking for an original creation it had to be new. As for the lack of adequate architects or the Church's traditional stand on art, he proposed a new competition with only sketches submitted, as this would solicit " contributions in line with the contemporary spirit, using completely new form, that the Church could then accept if it psychologically responded to religious needs $n$.

Other arguments not strictly related to style were also raised. Architect Dobrovic insisted that there were other needs than raising a monumental sized church. He proposed building a memorial building to St. Sava that would house different educational institutions and then separately build small churches in various Belgrade neighborhoods, which did not have them, as more appropriate to the memory of St. Sava. He also praised the Roman Catholic Church for its modernization efforts, for owning a radio station, building churches according to modern construction methods, and adjusting its liturgy to new spatial forms. By doing this, Dobrovic believed the Catholic Church " responded to the challenge of socialism and began to create its own socialism, neutralizing material arguments and advantages preached by Bolshevism $n$.

The polemic reached its peak when the Belgrade section of the Association of Yugoslav engineers and architects on February 11, 1932, demanded from the Construction Committee, the Ministry of Public Works, the Patriarch and the King the re-opening of the competition. Previously, the King's decision to illustrate the Royal Mausoleum Church with mosaic copies of medieval icons instead of opting for original artistic contributions was also widely criticized but in vain ${ }^{56}$. But this time King Aleksandar vetoed the decision of the Committee

54 Xašanin (Milan), " Skice za hram Svetog Save " (Sketches for St. Sava Church), Srpski knjiżevni glasnik, 21, 1927, p. 32.

55 The article from Srpski knjizevni glasnik, 35 (5), 1932, reprinted in Intervju, o1/04/88, pp. 66-68.

${ }_{56}$ Jovanovic (Miodrag), Oplenac (op. cit.), pp. 236-238. 
to commence construction 57 . It was only then that one of the chief designers, Deroko, finally entered the debate defending the expertise of the Committee and rejecting a Modern form for a sacral construction : " St. Sava Church is inextricably linked to an old Church and its religion, which draws its strength from such a rich past and architectural tradition so that even a contemporary ruler did not hesitate to build his palace except in the style of his distant predecessors ${ }^{58}$.

After pressure from the Patriarch, the King eventually withdrew his objection and the preparations could proceed. The works commenced in 1935 , with a spectacular procession led by the Patriarch Varnava and more than 1000 priests. The Assembly of Bishops dedicated the whole year to St. Sava and much was done to intensify the collection of funds for the construction of the Vraçar Church. Still, the reply was weak and the best explanation comes from the Construction Committee report :

insufficient or nonexistent preparation of the society for such effort, disputes about the true location where the relics were burned, no clear vision about the greatness of the task and the amount of money necessary to build it, poverty, poor performance of the fund raising committees, Bishops who focused on the more needy tasks, disputes among political parties which prevented any common actions. The Church itself was not spared from these disputes. (...) There was no interest of State, government and local authorities either, which further contributed to the general lack of response among the people. 59

The colossal dimensions of the St. Sava Church remained an idealized picture of the State thorn apart by ethnic grievances and regional differences and of the society having recently abandoned its egalitarian principles to encounter serious class and power divisions. By 1941, only the base was constructed and the whole church raised to the height of around ten meters.

\section{THE SECOND TRY}

The Second World War halted construction for many years. During the war, the Wehrmacht used the construction site as a garage and in 1944, turned it into a fortified defense against the advancing Russian and Partisan

\footnotetext{
57 Pešić (Branko), op. cit., p. 57.

$5^{8}$ The Palace for King Aleksandar was in fact built in the twentieth century academic style with the ornaments reinterpreting the medieval churches in Serbia of the so-called Morava style.
}

59 Izvestaj Društva za podizanje hrama Sv. Save u Beogradu-na Vračaru za 1938 godinu (Report of the Society for the Construction of St. Sava Church on Vračar Hill in Belgrade for 1938), Beograd : Privrednik, 1939, pp. XXIX-XXX. 
troops $^{60}$. The Serbian Orthodox Church as a whole suffered a savage assault during the war, and the after-war communist takeover reinforced this assault. The new communist authorities expropriated the construction site and closed it. Years of tense Church and State relations precluded any possibility of building such a monumental church in the capital of socialist and federative Yugoslavia ${ }^{61}$. The sixties and seventies brought some stability in Church and State relations, but the numerous appeals of Patriarch German, who headed the Serbian Church through these years, for the return of the land and continuation of works were nevertheless repeatedly repelled ${ }^{62}$. The issue provoked bitter disputes within the Church as well as some clergy criticized the Patriarch for being too cautious and circumspect in his dealings with the government ${ }^{63}$.

Asking for the renewal of construction, it was argued that so many monuments were being built to recent heroes [Partisan fighters from the WWII or communist ideologues], while the Orthodox flock was prevented to commemorate a great personality from the distant past, who also inspired people's fight for freedom, justice and honesty. It was also claimed that the Church wanted to give the city a remarkable architectural monument that would with " its size and spectacular dome become a crown of Belgrade, connecting its numerous buildings, which were scattered like Babylonian towers, creating a sense of unity and fullness, giving a beautiful silhouette and great appearance "64. Theologian Vladan Popovic in a series of texts in the late sixties placed the issue within the contemporary international debate and criticism of modernist architecture and urbanist concepts, defining the Church of St. Sava as a return to an essential aesthetic and human values as opposed to the dehumanizing and automatized modern city. The Church, he stressed, wished to foster internal growth of personality, one's freedom, choice, beauty and values of life as well the "primitive" sense of roots, which directly conditions man's openness to the world ${ }^{65}$. Still, arguments describing the church as a means of

\footnotetext{
60 Pešić (Branko), op. cit., p. 9.

${ }^{61}$ See Alexander (Stella), Church and State in Yugoslavia since 1945, Cambridge : Cambridge University Press, 1979 ; and the chapter on Serbian Orthodox Church in Ramet (Sabrina Petra), Balkan Babel, Boulder : Westview Press, 1996, pp. 165-184.

62 Perica (Vjekoslav), Balkan Idols. Religion and Nationalism in Yugoslav States, Oxford : Oxford University Press, 2002, pp. 125-126.

63 Stanković (Slobodan), " The LCY (Communist Party of Yugoslavia) Fears a Religious Revival ", Radio Free Europe Report, 28/03/85. On the Patriarch's appeals, Pešić (Branko), op. cit., p. 83.

64 Stefanović (Miodrag D.), “ Hram Sv. Save ", in Srpska pravoslavna crkva 1920-1970 (op. cit.), p. 132.

65 Teološki pogledi, 1968 and 1969. Similar arguments were put forward by the proponents for building the Koçatepe Mosque in Ankara (Turkey) in the context of the Atatürk Memorial and Modern architecture. See Meeker (Michael E.), « Once There Was, Once There Wasn't. National Monuments and Interpersonal Exchange ", in Bozdoğan (Sibel), Kasaba (Reșat), eds., Rethinking Modernity and National Identity in Turkey, Seattle : University of Washington Press, 1997.
} 
humanization, openness to the world, a symbol of people's common struggle for good and human prosperity, in the late sixties and seventies could not but fall on the deaf ears of the inimical authorities. Popović's texts, which referred to the global debate on modernity in architecture from religious angle also went unnoticed by the Serbian intelligentsia completely disassociated with the Church at the time.

The walls of St. Sava Church erected before the war remained, resembling a ruin, which constantly awakened the memory and, as Patriarch said in one of his epistles, recalled the notion of an "open wound" 66 . Another cleric called them "weeping walls". The suffering of the Church together with her people during and after the World War Two only deepened the identification of Serbdom and Orthodoxy. "The war and the period after ", wrote Metropolitan Amfilohije, "were like the new burning of St. Sava's relics, the renewed attempt to destroy, humiliate and frighten the spirit of the Orthodox Serbs as once was the aim of Sinan Pasha. The crucifixion of St. Sava's people became the crucifixion of St. Sava's Church. "67 For Serbian dissident nationalists, the "open wound" of the Church of St. Sava also stood to illustrate Serbian grievances over their being persecuted in Kosovo or the constitutional discrimination against Serbia within Yugoslav federation. As the dead body of a saint suffered, now the Church to his memory suffered, evoking the most suitable image for the dominant national ideology of suffering and martyrdom in Eastern Europe, of which the Serbs were not least representative ${ }^{68}$.

During the years of repression, the communist regime in Yugoslavia was the most sensitive to churches acting as outlets of national(ist) feeling. What it couldn't promote at home the Serbian Church insisted on abroad where most of the churches built for the Serbian Diaspora during this period were dedicated to St. Sava, testifying to the unabated resolve to the principles of identification of nation and religion as forged in the inter-war Svetosavlje ideology 69 . The revival of religion in the eighties further intensified this imagery. This revival was also a manifestation of the deep crisis of the communist ruled Yugoslav federation in the early nineteen eighties. Before, the regime was divided as to the demands for the continuation of the construction of the church with majority perceiving it as a bare display of Serbian nationalism. Now the

\footnotetext{
${ }^{66}$ Pešlé (Branko), op. cit., p. 142.

67 Radović (Amfllohije), art. cit., p. 185.

68 Verdery (Katherine), op. cit., p. 114
}

69 For other churches dedicated to St. Sava see Pavlovic (Leontije), Kultovi lica kod Srba i Makedonaca (Personal Cults by Serbs and Macedonians). Smederevo, 1965, pp. 63.65; and Jankovic (Milan D.), "Hramovi Svetoga Save u Srpskoj pravoslavnoj crkvi " (Churches Dedicated to St. Sava in the Serbian Orthodox Church) in Spaljivanje moštiju Svetitelja Save (The Buming of Holy Relics of St. Sava), Beograd : Sveti arhijerski sinod SPC, 1997. 
change was inevitable or desirable. The President of the Serbian Republic within the Yugoslav Federation, Dušan Čkrebić, who on June 19, 1984, received the Serbian Patriarch German to finally grant him the approval for the resumption of works, recently testified :

with no difficulties I got the approval from all the leading people in the republic to lift the ban on the church's construction. There was no one against it. (...) The older Serbian political leaders, who had been in office when the decision to ban the construction was taken, did not make any difficulties, manifesting in that way their silent solidarity with us, younger ones, but also redeeming for one political decision made long time ago, which insulted the Serbian people for years. $7^{70}$

This major shift happened before Miloševic rose to prominence and was employed by the party elite that he replaced few years later accusing them of betraying the Serbian national interests. It marked a gradual shift in the ideological focus of Yugoslav communists. After Tito's death, it was just a matter of time when and which of the ruling communist elites in the Yugoslav republics would embark on a new track. How quickly the Serbian communists became ardent supporters of the construction effort is illustrated by the words of Dragan Dragojlović, the Serbian Minister for Religious Affairs in the mid-nineteen eighties :

a historic time and collective misfortune over centuries of yoke have made this historic personality (St. Sava) a spiritual founder of Serbian identity. (...) The church dedicated to St. Sava, which is being built on Vračar, with its current dimensions obviously exceeds the usual needs of a church. However, with its size, the church probably strives to cover the life and deeds of St. Sava, or historic spaces of his personality and in a way to bring them to life, as well as the legends, real and desired, historic and irrational, which is all part of one consciousness, ready to, in its time and according to its tradition, commernorate a part of its history and thus commemorates itself as well. ${ }^{11}$

Endowing the Serbian Church with the task of commemorating the nation and virtually representing it, the Serbian Communists initiated a reordering of meaningful worlds that ensued in Eastern Europe after 1989, which Verdery described as reinserting expressly sacred values into political discourse $^{72}$. The continuation of works was supposed to remedy the havoc wrought on the social, cultural and political tissue of the nation during the previous forty years. Together with the carrying of the bones of Prince Lazar across the country as a part of the commemoration of the Battle of Kosovo, the construction of the church was the major symbolic attempt at reordering, reaf-

70 Ckrebić (Dušan), "Zidanje hrama "(The Building of the Memorial Church), Vreme, (557), $24 / 01 / 02$.

${ }^{7}$ Dragan Dragojlović in a special statement to Intervju, 01/04/88, p. 51.

${ }^{72}$ Verdery (Katherine), op. cit., p. 37. 
firming and bonding the nation ${ }^{73}$. Metropolitan Amfilohije, one of the most active Church hierarchs, spoke of the St. Sava Church " being resurrected after many years of being crucified with a deeper meaning that it had at the beginning " elaborating:

from the initially conceived monument of deep gratitude to the first Serbian Enlightener, this church is acquiring an all-encompassing essence and meaning.

(...) Overcoming its crucifixion and resurrection and turning into an all-encompassing sign of not only regional, Serbian but a universal character, the Church of St. Sava becomes a challenge and call to all, to a radical change and transformation of thought, knowledge and ability, or the ways of living and thinking in general. 74

The Church commissioned a renowned architect Branko Pešić as Chief Architect (Proto-Master) and consecrated the ground for a second time on May 12,1985 . More than a hundred thousand people gathered for yet another pompous open-air ceremony radiating two visible messages. The beginning of the work on the site, where it was so abruptly halted almost fifty years before, symbolically excised the time in between, breaking off with the recent rejected past and adjoining the distant idealized one. Secondly, the reports from the celebration projected an image of a vast throng of believers coming from all over the nation and assembling and uniting in front of the church. The presence of an immense crowd was in itself to justify the immensity of the church and its significance.

In his speech the Patriarch recalled how the spirit and legacy of St. Sava helped its fatherland to " overcome huge temptations through the centuries, to resist and survive Marica's catastrophe and the Kosovo tragedy, the Albanian Golgotha and Jasenovac (...) guarding its national name, religion, language, customs, its Christian, Orthodox and the spirit of St. Sava "75. In this exemplary time compression, among the four temptations mentioned, two are from the fourteenth and two from the twentieth century. The two former were battles that resulted in the loss of the Serbian medieval Kingdom to the Ottoman invaders while the latter refer to the immense human losses Serbs experienced during the course of two world wars ${ }^{7}$. By remembering the dead and death itself on the site of the future Memorial Church, the Patriarch called

73 Prince Lazar, killed as the leader of the Serbian forces in the Kosovo battle in which the Serbs lost their independence to the Ottomans, was also proclaimed as saint and his cult is second to that of St. Sava. Verdery sees in the ritual carrying of Prince Lazar's bones also an attempt to set the boundaries of greater Serbia (ibid., p. 18).

74 Radooic (Amfilohije), art. cit., p. 185.

75 Pešic (Branko), op. cit., p. 80 .

$7^{6}$ "Albanian golgotha" was the retreat in front of united Austro-Hungarian and German forces in 19151916 that cost Serbia's army and people many lifes. Jasenovac was the biggest concentration camp in fascist Croatia during WWII, where the Serbs were the principal victims. 
upon the meaning of the monument, similar to the one proposed by Vernan in his study of the ancient Greek colossus, whereby the colossus, while substituting the corpse in the depths of the grave, embodies and immortalizes not the dead, but life beyond death ${ }^{77}$. The Patriarch's speech uses death and glorifies the self-sacrifice of the dead to awaken and nourish the spirit of the people after forty years of communist rule in light of the problems of Serbs in Kosovo and economic crisis across the whole country. There was no better myth for awakening, for the cult of St. Sava's embodies and immortalizes self-sacrifice for the sake of the people. The Memorial Church provided the visual imagery for Christian notions of the suffering and resurrection, easily translatable to the political rhetoric of the revival of the strength and spirit of the Serbian people, after years of humiliation and defeat.

In a fund raising speech given in Los Angeles, poet Matija Bećković also saw in the St. Sava Church an embodiment of all Serbs and all of Serbia : "we are not gathering [funds] for the Church - we are gathering ourselves. (...) St. Sava Church does not belong to anyone, we belong to it. It is built by all times and by all generations, by our Patriarchs, ancestors, forebears and fathers. (...) St. Sava Church is all of Serbia ${ }^{78}$.

The featuring of dead ancestors is a crucial point of reference for the living in modern nationalism. The past had to win over the present through the Memorial Church, whose victory was already accomplished, as Metropolitan Amfilohije professed, in the victory of the scattered and indestructible ashes of St. Sava on which it was to be built. Matija Bećkovic coined a motto - "We are not building the Church, the Church is building us ". Few remembered that some forty years earlier communist propagandists used the same motto in mobilizing the youth to volunteer their labor in the reconstruction and industrialization of the country. Their version was : " we are not building the railway, the railway is building us ".

The works were ambitiously conceived. Donations were collected all over the world and forecasts were made that, with new technology means, in a few years the greatest Orthodox Church in the world could be built " despite all earthly obstacles and in order to prolong the life of tradition and myth of St. Sava ". The chief architect envisaged the building of a crypt chapel dedicated to the Kosovo martyr St. Lazar, a treasury to hold all the nation's cultural treasures, a cinema and big concert and lecture hall and library where the added functions obviously expressed the new role of the Serbian Church in society and the all-encompassing importance of the national monument under conspitre “ Figuration de l'invisible et catégorie psychologique du double : le colossos $»)$.

$7^{8}$ Becković (Matija), art. cit., p. 11. 
truction 79 . The original project was modified and now it was expected that the church would be capable of receiving up to 15 thousand people which is more than any other Orthodox Church in the world can receive 80 .

Fifty years after the famous polemic among Belgrade's architects, there were considerably fewer debates and certainly less fury over the church's design. The architectural reversion corresponded to the intended symbolism of the reversal of the communist practice accused of eradicating Serbian religious and national consciousness. The opting for the old design as a powerful image of the presumed break with the communist past and the beginning of the new epoch will be later repeated with Moscow's Church of Christ the Saviour ${ }^{81}$. Astonishingly, little criticism was raised even though the construction followed the same project under drastically different conditions of the site and its visual and spatial arrangement in a new setting. The church's architect Branko Pešić could proudly declare : " the Constantinople church definitely marks a beginning of great Byzantine architecture, which we are ending fourteen centuries later $n^{82}$.

Few, like Dobrovic before the war, questioned the idea of building such a colossal church, its sheer size being a modern and Church's most notable feature, and protested to the immoderate calling for the church to become the biggest Orthodox church in the world. An article in the Church journal warns that the monumentality and architectural features of St. Peter's in Rome are fully enslaved to its representational function, almost disabling the discreet spiritual reintegration of a Christian pilgrim but provides only obscure arguments why the same should not apply to St. Sava Church ${ }^{83}$. In the meantime, hundreds of new neighborhoods arose all over the country, without places of worship, such as New Belgrade with over 200000 inhabitants. In the only protracted discussion on this matter, Metropolitan Amfilohije acknowledged the magnitude of the church as its largest challenge : " external monumentality was always man's conscious or unconscious attempt to cover with external effect and force his internal fear, helplessness, misery and spiritual poverty " 84 . The Metropolitan's major objections however, concerned the application of modem building techniques and materials such as concrete and prefabricated blocks. Most of his remarks remained unanswered as Serbian Church hierarchy and contractors rushed to complete the construction and sought to see the

39 All of these ambitious plans were later abandoned. Pešic (Branko), op. cit., p. 115.

${ }^{80}$ Pešic (Branko), Godine hrama Svetog Save, Beograd : M. komunikacije, 1995, p. 60.

${ }^{81}$ sidorow (Dmitiri), art. cit., p. 548.

${ }^{82}$ Intervju, 01/04/88, p. 77 .

${ }^{8}{ }_{3}$ Mojovié (Dragan), "St. Sava's Church as the Oath of Return to the Center ", Teološki pogledi, 1999.

84 Radović (Amfllohije), art. cit., p.186. 
end of Serbian misfortunes with the completion of their Memorial Church. The idea to build a Memorial Church to St. Sava, according to the same project and on very spot where it was halted by communist authorities was simply overwhelming ${ }^{85}$.

In an exemplary act that illustrates the nationalist strive to demonstrate symbolically the Serbian national unity and resurgence, the Episcopal Synod in 1988 approved a cross, specially designed to be placed on the dome of St. Sava Church by sculptor Nebojša Mitrić ${ }^{86}$. The cross that the Synod described as "the Cross of Saint Sava" was the Greek cross decorated with four Cyrillic letters -s- (c), standing for the traditional Serbian slogan "samo sloga Srbina spašava" (only unity saves the Serbs). This decision not only reiterated the political intentions behind the church's construction, present from its very inception, but brought it to the extreme since, as some critics had it, the design was clearly non-canonical and thus indicated the Synod's preference for the rallying effects of the national monument rather than the traditionally conceived church building.

The construction work continued paralleled with the deepening of political and economic crisis in Yugoslavia, with conflicting interests of leaderships of its constitutive parts being the greatest danger for its survival. Serbia led by Milošević spearheaded the nationalist hysteria that even rose some eyebrows in the Serbian Church. In their annual epistle on St. Sava's day in 1988, Patriarch and the Bishops warned :

the State must not be an Empire, while where Empire begins Fatherland ceases to exist. Therefore, it is a big misfortune to oppress other peoples, just as it is to be oppressed from the others. (...) Saintsavaian patriotism was born in silence and joy of creation without chauvinist selfishness and blood spilling. Along with it arose the sense of the need to share its people's heritage with other peoples and the wish for accepting other peoples' cultural wealth. ${ }^{87}$

Soon, serious inflation and an economic crisis slowed the pace of the construction work on St. Sava Church. In 1990, the economic crisis yielded as a primary concern to that of the very existence of the Yugoslav State. The next year, the State collapsed into a bloody war for the second time in fifty years, only this time without foreign occupation to precede it. At the same time, serious affairs wrecked the building efforts. Once the cupola was lifted and the church roofed, the next task envisaged was to cover it in marble. Most of the remai-

\footnotetext{
${ }^{85}$ Certain revisions of the plan were undertaken but only in relation to the technical feasibility or details such as lighting, acoustics etc. Pešic (Branko). Spomen hram Sv. Save na Vračaru u Beogradu 1895-1988 (op. cit.), pp. $114-117$.
}

${ }^{86}$ Pešić (Branko), “ Spomen hram Svetoga Save na Vračaru ", in Spaljivanje moštiju Svetitelja Save (op. cit.), p. 366.

${ }^{87}$ Intervju, $01 / 04 / 88$, p. 97. 
ning money was spent on purchasing the marble plaques, which soon were discovered to be radioactive. Other rumors held that the structure was sinking. The works were stopped, Chief Architect Pešić resigned and numerous accusations resounded in the press.

The tragic circumstances and the results of wars waged from 1991, have shifted people's attention from the Vracar Church as the source of their unity and revival. The aspiration for lavishness vanished as the ideological constructs of national reaffirmation and resurrection did not materialize. A new common myth appeared suggesting that the church must not be completed because by the time this happens there will be no Serbs left. The myth's justification argument combines the senselessness of the last wars, which claimed the lives of so many Serbs along with others, with the unattainable ideals embodied in the construction of the Church of St. Sava.

\section{EPILOGUE}

After years of oblivion the Serbian Church in mid-199os drew attention back to the St. Sava Church and began holding services on the plateau in front of the construction site or recently even inside the unfinished church. The Chief Architect Pešić appealed :

let us get out of this war and hell with the biggest ever victory, with the fulfillment of the Serbian people's oath to erect the church to its Enlightener St. Sava on the very spot where four hundred years ago his holy relics were burned with the aim to destroy what was the holiest and best in the Serbian people. Let us finish the church as a proof that we can not be defeated, let us prove that the ashes of St. Sava were not in vain ! Everything else would mean the victory of Sinan Pasha, of all our occupiers, old and new enemies. ${ }^{88}$

In the atmosphere of the complete breakdown of the Serbian society, where basic economic and political security could not be provided, not to mention spiritual or cultural revival, "Serbian National Cathedral" was again hailed as a celebration of "victory over the enemy" and the segment of its role as the act of societal repentance for the communist era was lost ${ }^{89}$. In the year 2000, after the overthrow of Miloševic and almost a ten-years break, the works has begun again. In a striking contradiction to the proclaimed vision of the St. Sava Church as the endowment of the nation, the new Serbian Prime Minister -

\footnotetext{
${ }^{88}$ Đordević (Duška), "Zvona zvone, hram ne tone "(Bells are ringing, the Church is not sinking), Oko, 2000, p. 4.

89 See Merick (Rade), "The Serbian National Cathedral ", in 1998 Calendar of the Serbian Orthodox Church in the Unided States of America and Canada.
} 
Đinđić urged a few profitable State and private banks and companies to donate in order to complete the church by 2004. The Royal family, which came to settle in the country, after Milošević was ousted, also joined the effort $9 \circ$.

But the new beginning was again marred by controversy, this time regarding the bells bought from the Austrian bell-maker Grossmayer. Their recent installation and ceremonial ringing was supposed to announce the continuation of the construction efforts and moreover an appeal to all for prayer and repentance, so needed after the most recent troubled events ${ }^{91}$. State ministers sponsored some of the forty-nine expensive bells delivered from Innsbruck, which were made to play in four octaves and to perform the hymn of St. Sava every day at noon. The critics immediately pronounced this Glockenspiel-like device against Orthodox canons and described it as a manifestation of Orthodox kitsch and nationalist hysteria ${ }^{92}$. Others protested that the bells were made in Austria by a Catholic Church bell-maker. But the largest disappointment came with their first performance, when even those standing in front of the church could not hear them ring, despite promises that the sound should reach twenty kilometers. Because of either acoustics, position or quality of the bells, fiery discussions erupted once again reflecting the central role of St. Sava Church in the contest of visions of how the nation should be commemorated. More than a century after its construction was initiated, the Church on Vračar Hill is still awaiting completion and to assume the monumental and memorial role it was assigned. Manifesting Serbian unity and resurrection seems to be as hard now as it had been anytime over the last century.

9o Mikić (Verica), " Hram ćemo ipak završiti " (We Will Eventually Finish the Church), Glas Javnosti, $14 / 11 / 00$.

${ }^{11}$ Jovic (Rev. Savo B.), “ Osvećena zvona za Spomen-hram Svetog Save na Vračaru "(The Bells for the Memorial Church of St. Sava on Vračar Hill Consecrated) on Serbian Orthodox Church News Internet Page

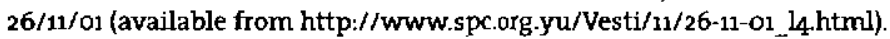

92 Panovic (Zoran), "Glokenšpil kao pravoslavne orgulje "(Glockenspiel as Orthodox Organ), Danas, 05/01/02 ; Simonovic (Petar), "Sapat svetosavskih zvona " (The Whisper of St. Sava's Bells), Reporter, 30/04/02. 